\title{
Screening for HIV-1 antibodies in pregnancy: results from the Swedish national programme
}

\author{
Susanne Lindgren, Ann-Britt Bohlin, Marianne Forsgren, Malin Arneborn, Christina Ottenblad, \\ Knut Lidman, Bo Anzén, Madeleine von Sydow, Margareta Böttiger
}

\author{
Abstract \\ Objective-To determine the effectiveness of a \\ national screening programme for HIV infection in \\ pregnant women. \\ Design-Observational study. \\ Subjects-All pregnant women presenting to ante- \\ natal or abortion clinics.
}

Setting-Sweden, September 1987 to December 1991.

Main outcome measures-Number and characteristics of infected women.

Results-By the end of the study period 510000 tests had been performed and 54 women with HIV infection identified $(1 \cdot 06 / 10000)$. Of the 33 women identified in Stockholm, 14 women $(4 \cdot 4 / 10000)$ had attended abortion clinics and 19 antenatal clinics $(1.8 / 10000 ; p<0.05)$. Three women had been intravenous drug users, one was infected through a blood transfusion, and 50 were probably infected sexually. Of the 20 women who attended antenatal clinics early enough to allow an abortion, 12 continued with their pregnancies.

Conclusions-Testing of all women, not just those perceived to be at risk, probably contributed to the high uptake of HIV testing. With high uptake such screening provides valuable data on spread of HIV in the heterosexual population and presents opportunity for preventing transmission of HIV to children and partners.

\section{Introduction}

An increasing number of women of childbearing age throughout the world are becoming infected with HIV-1, and $13.39 \%$ of their children are also infected during pregnancy, delivery, or breastfeeding. ${ }^{1-4}$ In 1987 the National Commission on AIDS recommended that pregnant women in Sweden should be offered an HIV antibody test. Testing of large populations allows surveillance of the epidemic and has been widely encouraged and used in Sweden. ${ }^{5}$ Sweden also has a mandatory reporting system for certain contagious diseases, which is administered by the epidemiological department of the national bacteriological laboratory. Clinicians and laboratories report in code all people with HIV infection. By 31 December 1991 almost 3000 seropositive people had been identified in Sweden. Two thirds of them had been tested in Stockholm, where one fifth of the country's 8.6 million inhabitants live. ${ }^{6}$

In September 1986 a pilot study of screening for HIV antibodies in pregnant women living in southwest Stockholm was conducted from Huddinge Hospital.? Pregnant women were offered an HIV test together with the prenatal screening tests for rubella and syphilis at their first visit to the antenatal care unit. The test was also offered to women applying for legal abortion. All pregnant women were offered the test irrespective of ethnic background and known risk behaviour to ensure that testing would not be perceived as discriminatory. Before the project was started, a strategy for counselling and providing care for the infected pregnant women identified was worked out by a multidisciplinary team. The programme was well accepted. ${ }^{8}$

In 1987 the Swedish national board of health and welfare issued recommendations concerning HIV screening in pregnant women based on the experiences with the pilot project (appendix). It stated that an organisation for the care of identified HIV positive women was a prerequisite for screening. ${ }^{9}$ We report the results and experiences from the pilot project as well as the nationwide HIV screening programme.

\section{Methods}

Maternal health care in Sweden is uniformly organised and free of charge. There are about 700 antenatal care units in the country and $98 \%$ of pregnant women attend these units. ${ }^{10}$ Urine tests to confirm pregnancy are done by the midwife, which enables her to establish contact with the woman in early pregnancy. Termination of pregnancy before gestational week 19 is legal and available for all women living in Sweden. Accordingly, the number of illegal abortions is negligible. Women who continue with their pregnancies are supervised by the midwife throughout the pregnancy, and an obstetrician is available when required. Every year about 120000 children are born in Sweden and 35000 legal abortions are performed.

Since 1 September 1987, a test for HIV antibodies has been offered along with other blood tests in most antenatal care units in Sweden. The HIV test is also offered to all patients in some abortion clinics, almost all in Stockholm county and some in other parts of the country. In 1990 a questionnaire was sent randomly to the midwives at 344 of the 700 antenatal care units in Sweden to assess the screening procedure routines. The questions focused on how the HIV test was presented to the women. In 298 of the 299 responding units, the women were informed that the HIV test was part of the routine antenatal screening procedure. In 269 of the units the women were informed that the test was voluntary and in 263 they were recommended to have the test done.

\section{LABORATORY TESTS}

In the one year pilot study in Stockholm, 7708 tests were analysed by the central microbiological laboratory of Stockholm County Council. Samples were analysed with two commercial HIV-1 enzyme linked immunosorbent assays (ELISA), one antiglobulin test (Dupont, Switzerland), and one competitive ELISA test (Wellcome Diagnostics, United King- 
dom). Samples from immigrants from regions where HIV-2 infection is known to occur were also analysed for HIV-2 by ELISA (Pasteur, France). Sera that were repeatedly reactive in either or both tests were tested by western blotting (WB, BioRad, United States; Diagnostic Biotechnology, Singapore) and immunofluorescence. ${ }^{11}$ In this first phase, samples with activity just under the cut off point were also included. Samples unequivocally positive in the two confirmatory reactions were reported as positive and a second blood sample was requested for confirmation.

In the extended testing programme in Stockholm after 1 September 1987, duplicate analyses were omitted. The specificity and sensitivity of the tests have improved, and repeatable non-specific reactivity in the HIV-1 ELISA antibody test has become less common $(<0 \cdot 1 \%)$. Since June 1989 , a recombinant test for HIV-1 and HIV-2 has been used (Combo, Abbott, United States). When commercial HIV antigen tests became available, one such assay (Abbott) was included in the tests of serum samples giving indeterminate results on western blotting to exclude early primary infection (in the western blot two envelope bands were required for confirmation of the HIV diagnosis).

The antenatal screening tests for HIV in other regions of Sweden were performed by the regional virus laboratories, and in some places also by clinical bacteriological laboratories under the supervision of the regional or national reference laboratory. The high standard of the testing procedures was guaranteed by analysis of control panels of serum samples distributed by the national reference laboratory.

\section{REPORTING SYSTEM}

Laboratories where HIV tests are performed send monthly reports of the number of seropositive individuals (in code) to the national bacteriological laboratory. Twenty three of the 24 counties in Sweden participate in the HIV screening programme. Eighteen counties report the number of HIV tests in pregnant women separately, and also the number with positive results. Samples from abortion clinics and antenatal care units are not separated. Five counties do not report the number of negative results in pregnant women separately.

Stockholm has the highest incidence of HIV infection in Sweden. ${ }^{6}$ We selected a region covering most of Stockholm county and served by one laboratory for validation of the epidemiological data obtained in the screening programme. Anonymous HIV testing was done on stored serum samples from pregnant women sent to the laboratory for rubella immunity testing but with no request for HIV antibody analysis. With the permission of the ethics committee of the Karolinska Institute, serum samples were analysed anonymously for HIV at least six months after the woman's estimated time of delivery. The number of samples analysed on each occasion was at least 100 .

\section{Results}

From 1 September 1986 to 31 December 1991 about 510000 blood samples were analysed in the HIV screening programme for pregnant women (table I). Fifty four women, aged 14-36 (mean 26) years were identified as HIV positive, corresponding to $1 \cdot 06 / 10000$ tests. Table II shows that the number of HIV positive tests was significantly higher in Stockholm county than in the rest of the country $(p<0.001$, $\chi^{2}$ test). In Stockholm, 14 out of about 32000 tests $(4 \cdot 4 / 10000)$ on serum samples obtained in abortion clinics gave positive results compared with 19 out of about 108000 tests $(1.8 / 10000)$ on serum samples from antenatal care units $\left(\mathrm{p}<0.05, \chi^{2}\right.$ test $)$.
A description of the epidemiological situation with regard to HIV in pregnant women in Sweden should also include women with known HIV infections who became pregnant during the study period and pregnant women whose HIV infection was diagnosed outside the screening programme-for example, in refugee camps. The total number of women known to be infected with HIV and delivered of babies in Sweden is available, ${ }^{12}$ but not the number of infected women who terminated their pregnancies. We estimated the number of infected women who terminated pregnancies in Stockholm county by contacting hospitals performing HIV screening in abortion clinics. Thus, in this area about 40 (14 in the screening programme) out of 32000 patients in abortion clinics were HIV positive $(12 \cdot 5 / 10000)$. Among women in antenatal care units in Stockholm, 36 (19 in the screening programme) out of about $108000\left(\mathrm{p}<0.001, \chi^{2}\right.$ test $)$ were HIV positive $(3 \cdot 3 / 10000)$.

Anonymous analysis of the serum samples from the women who declined the HIV test found no positive results (table III). The figures from Stockholm were calculated prospectively and reported throughout the study period. Figures from other parts of Sweden were estimated retrospectively and were available for only one third of the responding antenatal care units.

The most probable route of transmission for each of the 54 seropositive women, 15 of whom were Swedish, is given in table I. Three women were probably infected through intravenous drug use and one woman

TABLE I-Number of tests and number of HIV positive women identified in the Swedish screening programme for pregnant women

\begin{tabular}{lccccc}
\hline & & \multicolumn{4}{c}{ Probable route of transmission } \\
\cline { 4 - 6 } Year & $\begin{array}{c}\text { No of } \\
\text { tests }\end{array}$ & $\begin{array}{c}\text { No HIV } \\
\text { positive }\end{array}$ & $\begin{array}{l}\text { Intravenous } \\
\text { drug use }\end{array}$ & Sexual & $\begin{array}{c}\text { Blood } \\
\text { transfusion }\end{array}$ \\
\hline $1986-7^{\star}$ & 7708 & 3 & 1 & 2 & \\
1987 & 33224 & 1 & 1 & 10 & 1 \\
1988 & 89523 & 12 & 1 & 5 & \\
1989 & 97736 & 5 & & 10 & \\
1990 & 96890 & 10 & & 23 & \\
1991 & 98395 & 23 & & 50 & 1 \\
\hline $\begin{array}{l}\text { Total } \\
\text { Corrected } \\
\text { number }\end{array}$ & 423476 & 54 & 3 & 50 & 1 \\
\hline
\end{tabular}

ॠPilot project.

tAn estimated number of tests were added, corresponding to the number of births in the five counties without separate reporting of tests in pregnant women (see text under reporting system).

TABLE II-Results from the HIV screening programme for pregnan women, analysed separately for Stockholm county and the rest of Sweden

\begin{tabular}{lccc}
\hline & $\begin{array}{c}\text { No of } \\
\text { tests }\end{array}$ & $\begin{array}{c}\text { No of } \\
\text { HrV positive }\end{array}$ & $\begin{array}{c}\text { No of } \\
\text { positive } \\
\text { results/10 000 } \\
\text { tests }\end{array}$ \\
\hline Sweden, excluding Stockholm & $371116^{\star}$ & 21 & 0.57 \\
Stockholm county & 138884 & 33 & $2.38 \dagger$ \\
All Sweden & $510000^{\star}$ & 54 & 1.06 \\
\hline
\end{tabular}

${ }^{\star}$ Estimated figures.

tp $<0.001$ Compared with rest of Sweden.

TABLE III-Number of women who declined the HIV antibody test in the screening programme and results of anonymous testing of serum amples from these women

\begin{tabular}{|c|c|c|c|}
\hline & $\begin{array}{l}\text { No of } \\
\text { tests }\end{array}$ & $\begin{array}{l}\text { No (\%) who } \\
\text { declined }\end{array}$ & $\begin{array}{l}\text { No of positive } \\
\text { results among } \\
\text { declining women }\end{array}$ \\
\hline $\begin{array}{l}\text { Selected number of antenatal care } \\
\text { units }(1990)\end{array}$ & 14400 & $236(1 \cdot 6)$ & Unknown \\
\hline $\begin{array}{l}\text { Region of Stockholm covered by } \\
\text { central laboratory }\end{array}$ & 101555 & $3240(3 \cdot 2)$ & 0 \\
\hline Pilot project area† & 42109 & $192(0 \cdot 46)$ & 0 \\
\hline
\end{tabular}
${ }^{\star} 1$ September 1986 to 31 December 1991.
tSMCL, the Central Microbiological Laboratory of the Stockholm County
Council. 
TABLE IV-Demographic data, where HIV test was done, and the HIV status of the partners in relation to pregnancy decision or outcome

\begin{tabular}{|c|c|c|c|c|c|c|}
\hline & \multirow[b]{2}{*}{$\begin{array}{c}\text { Abortion } \\
\text { clinics }\end{array}$} & \multicolumn{4}{|c|}{ Antenatal care units } & \multirow[b]{2}{*}{ Total } \\
\hline & & Abortion & Miscarriage & $\begin{array}{l}\text { Child, } \\
\text { own choice }\end{array}$ & $\begin{array}{l}\text { Child, late } \\
\text { attenders }\end{array}$ & \\
\hline No of women & 17 & 8 & 1 & 12 & 16 & 54 \\
\hline \multicolumn{7}{|l|}{ Origin: } \\
\hline Europe & 6 & 3 & 1 & 5 & 3 & 18 \\
\hline Africa & 10 & 5 & & 5 & 10 & 30 \\
\hline Asia & 1 & & & 1 & 2 & 4 \\
\hline Americas & & & & 1 & 1 & 2 \\
\hline \multicolumn{7}{|l|}{ Marital status: } \\
\hline Married or cohabiting & 11 & 8 & 1 & 11 & 11 & 42 \\
\hline Single & 5 & & & 1 & 5 & 11 \\
\hline Unknown & 1 & & & & & 1 \\
\hline \multicolumn{7}{|l|}{ Partner's HIV state: } \\
\hline HIV positive & 3 & 4 & & 8 & 3 & 18 \\
\hline HIV negative & 5 & 4 & 1 & 3 & 7 & 20 \\
\hline Unknown & 3 & & & & 1 & 4 \\
\hline \multicolumn{7}{|l|}{ Previous children: } \\
\hline Yes & 6 & 4 & & 5 & 9 & 24 \\
\hline No & 9 & 4 & 1 & 7 & 6 & 27 \\
\hline Unknown & 2 & & & & 1 & 3 \\
\hline
\end{tabular}

was infected through blood transfusion. The remaining 50 women were probably sexually infected. We included women originating from endemic areas in sub-Saharan Africa in this last group, although other routes of infection such as blood transfusion and contaminated needles or syringes cannot be excluded.

Seventeen of the 54 women had HIV infection identified when they applied for legal abortion, and 37 were tested at antenatal care units (table IV). Of those tested at antenatal care units, one had a miscarriage and 16 attended the antenatal care unit too late in pregnancy for an abortion. In nearly all cases the reason for late attendance was immigration or returning from abroad in advanced pregnancy. Of the 20 women at the antenatal care units who could make informed decisions about their pregnancy, 12 continued with their pregnancies and eight elected for abortion.

Forty two women were married or cohabiting with the father of the expected child, and 38 of these male partners had HIV antibody testing-18 were HIV positive. Only three women had HIV related clinical symptoms and none had AIDS at the time infection was discovered. The clinical stage of the HIV infection was unknown for two women. The remaining 49 women were asymptomatic.

In March 1992, 10 women were lost to follow up, nine because of emigration. Of the remaining 44 women, four were or had been pregnant again-two chose to proceed with their pregnancies and two elected for abortion.

We estimated that 34 of the 54 women $(63 \%)$ probably could have been identified in a selective screening based on known or self identified risk factors for HIV exposure, provided that the women would have reported their risk factors and accepted the test under those conditions.

\section{Discussion}

For screening to be justifiable, the target disease should be either curable or there should be other obvious advantages from the person knowing he or she has the disease. HIV infection is not a curable disease. However, if identified, the patient can receive antiretroviral drugs, and prophylaxis against secondary infections, especially pneumocystis carinii pneumonia, can be started when the immune system is hampered.

Advantages for other people and the whole community strengthen the motives for screening. The pregnant woman is given the option to terminate the pregnancy to avoid the risk of giving birth to a child infected with HIV or a child that will be orphaned. Furthermore, she can refrain from breast feeding to avoid infecting her baby after birth. ${ }^{1314}$ She can also avoid infecting her sexual partner and prevent further pregnancies.

People infected with HIV also experience disadvantages from being aware of the infection when they are asymptomatic. The psychological burden of carrying the infection might cripple some people more than the disease. A discriminatory attitude in the community adds to the difficulties. For example, life insurance is not available for people with HIV infection. Furthermore, becoming aware of the HIV infection interferes with people's family and life planning and, when disclosed during pregnancy, necessitates facing their attitudes to abortion and to giving birth to a child who might be fatally ill. The woman and her partner need time and support to work through the emotional stress and to make an informed decision. ${ }^{15}$

Studies of the impact of being diagnosed with HIV on decisions about pregnancy have been done mainly on women using intravenous drugs. Selwyn $e t$ al found that the knowledge of HIV antibody status did not seem to influence the choice between abortion and continued pregnancy. ${ }^{16}$ In a study by Johnstone et al, all 15 women who were found to be infected with HIV at the antenatal clinic continued their pregnancies because they were in good health, desired to have a child, were against abortion, and knew other infected women whose children were well. ${ }^{17}$ Because of the small numbers of infected women identified we could not determine a pattern in decisions about pregnancy with regard to ethnic background, the HIV status of the partner, or whether or not the woman already had children. However, these factors, as well as other psychosocial, medical, and cultural factors, are important.

If it has a high acceptance rate, a screening programme for HIV in unselected pregnant women can give valuable information about the spread of the infection in the general population. Offering the HIV test to all pregnant women, irrespective of origin and risk behaviour, makes testing less difficult for the patient and this approach probably contributed to the high acceptance rate in our programme. It is important to know that in our population the few women who declined testing were not at high risk of HIV infection. Other studies have found opposite results. In a clinic for sexually transmitted disease nine out of 237 patients (3.8\%) who declined HIV testing were HIV positive compared with eight out of 1146 patients $(0 \cdot 7 \%)$ who consented. ${ }^{18}$

Unlinked anonymous HIV testing of neonatal metabolic screening cards is another method for monitoring the epidemic in the heterosexual reproductive population. ${ }^{19-22}$ This method has several shortcomings. The woman is not able to make an informed decision about the pregnancy or to prevent transmission to her partner. Furthermore, the method excludes women in abortion clinics, where the prevalence of HIV infection, in both this and other studies, is higher than in antenatal care settings. ${ }^{23}$

\section{COUNSELLING}

The large number of patients in this type of screening programme makes it difficult to offer in depth counselling before testing, which is claimed by some to be a prerequisite. ${ }^{24}$ However, the Institute of Medical Ethics has stated that pregnant women can be offered HIV testing on an opting out rather than an opting in basis. ${ }^{25}$ This means that the woman is informed about the test being a part of the routine procedures and that she has the right to refuse. All women should be given a briefing before testing, and intensive counselling should be available when a woman is found to be infected or at risk. ${ }^{25}$ People in Sweden have a fairly good knowledge of facts about 
HIV and AIDS, and the Swedish programme is based on an opting out model.

It is important that the woman should not feel forced to have the test done. ${ }^{24}$ The responses in our questionnaire showed that $10 \%$ of the midwives did not inform the women that the test was voluntary. This is not acceptable, and the education of the midwives should therefore be reinforced.

\section{VALUE OF UNSELECTED SCREENING}

If the HIV test had been offered only to women with known or self identified risk factors, the programme probably would have identified $63 \%$ of the seropositive patients, provided that these women would have accepted the test in a selective screening programme. This agrees with the findings of other studies. ${ }^{26-30}$ Barbacci et al identified 44 of $95(46 \%)$ infected pregnant women by a selective screening procedure. ${ }^{29}$ In a serosurvey of $\mathrm{HIV}$ in women giving birth in New York, cord blood samples from 602 infants were analysed for HIV antibodies. Twelve were positive but only seven of the 12 mothers of these infants had self identified risk factors. ${ }^{26} \mathrm{~A}$ non-selective screening programme seems to be the best way of detecting infected women.

Cost-benefit analysis of a screening programme is difficult. In France, attempts have been made to calculate the prevalence at which the cost of an antenatal screening programme is balanced by the avoided costs for the follow up and treatment of children of infected mothers (C Le Galès et al, eighth international conference on AIDS, Amsterdam, 1992; abstract 4824). At an abortion rate of $50 \%$, the prevalence of HIV infection among pregnant women must be at least 25 per 10000 . The prevalence in Sweden is much lower.

The economic benefits of prevention programmes are difficult to estimate-for example, the default costs for the care of orphaned children, infected sexual partners, and avoided future pregnancies. The estimated cost of identifying one infected pregnant woman in the Swedish screening is $\$ 96000$ ( $\$ 64000)$. However, the lifetime cost of treating one adult with HIV or AIDS in Sweden has been estimated to be $\$ 140000-\$ 280000(£ 93000-£ 186000)$-a cost which can be avoided if the virus is not transmitted further by the identified woman. ${ }^{5}$ None of the 25 women available for follow up who were identified in the abortion clinics or who chose to terminate the pregnancy had subsequently decided to bear a child.

We found a higher rate of HIV infection in women in abortion clinics in Stockholm, compared with those in antenatal care units. Similarly, Goldberg et al found that the prevalence of HIV infection in antenatal clinics in Dundee was $0 \cdot 13 \%$ compared with $0.85 \%$ among women applying for termination of pregnancy. ${ }^{23}$ Women who know that they are infected with HIV might be more likely to apply for abortion, but the difference remained when only women with previously unknown HIV infection were compared $(0.2 \%$ in abortion clinics and $0.06 \%$ in antenatal clinics). ${ }^{23}$ Women applying for abortion are therefore an important target group for measures to prevent HIV infection, and expanded HIV testing in abortion clinics should be considered.

\section{CONCLUSIONS}

This study shows that named screening of pregnant women can be done on a large scale. To achieve a high acceptance rate it is important that those who offer the test are competent and highly motivated to recommend the test. ${ }^{31}$ We believe that our experiences can be useful for others, although it may not be possible to transfer the programme to other countries. People in Sweden have, by tradition, great confidence in the health care

\section{Epidemiological implications}

- Increasing numbers of women of childbearing age are becoming infected with HIV

- Knowledge of infection early in pregnancy allows women to make informed decision about the pregnancy and take steps to prevent transmission to their baby and partner

- Since 1987 all women in Sweden have been offered an HIV test as part of the routine tests at the first antenatal visit. Tests have also been offered at some abortion clinics

- Most women accepted the test and $54 \mathrm{HIV}$ infected women had been identified; most had probably been infected sexually

- Non-discriminatory antenatal screening programmes can provide valuable data on the spread of AIDS

measures provided by the authorities. However, most important is the motivation of those being screened, and most pregnant women are highly motivated and capable of making decisions concerning the ongoing pregnancy and future family planning.

This study was supported with grants from the Karolinska Institute; the Medical Research Council, project No B9316H-10395-01A; and the Swedish Physicians Against AIDS Research Foundation.

1 Ryder RW, Nsa W, Hassig SE, Behets F, Rayfield M, Ekungola B, et al. Perinatal transmission of the human immunodeficiency virus type 1 to infats of seropositive women in Zaire. N Engl f Med 1989;320:1637-42.

2 Blanche S, Rouzioux C, Guihard Moscato MI, Veber F, Mayaux MJ, Jacomet C, et al. A prospective study of infants born to women seropositive for human immunodeficiency virus type 1. N Engl f Med 1989;320:1643-8.

3 Tovo PA, de Martino M, Gabiano C, Cappello N, D'Elia R, Loy A, et al. Prognostic factors and survival in children with perinatal HIV-1 infection. Lancet 1992;339:1249-53.

4 European Collaborative Study. Children born to women with HIV-1 infection: natural history and risk of transmission. Lancet 1991;337:253-60.

5 Blaxhult A, Anagrius C, Arneborn M, Lidman K, Lindgren S, Böttiger $M$ Evaluation of HIV testing in Sweden 1985-1991. AIDS (in press).

6 Swedish National Bacteriological Laboratory, Department of Epidemiology. HIV-och aidsstatistik, Sverige to m 911231. Epid-aktuellt 1991;14(12):6.

7 Larsson G, Lindgren S, Ottenblad C, Wager J. HIV screening av gravid kvinnor-ett års resultat och erfarenheter. Ldkartidningen 1988;85:332-3.

8 Larsson G, Spångberg L, Lindgren S, Bohlin A-B. Screening for HIV in pregnant women: a study of maternal opinion. AIDS Care 1990;2:223-8.

9 Socialstyrelsens allmänna råd om HIV-screening av gravida kvinnor. Socialstyrelsens författringssamling 1987;22:1-4.

10 Larsson G, Spángberg L, Theorell T, Wager J. Maternal opinion of psychosocial support: evaluation of an antenatal programme. $₹$ Adv Nurs 1987;12: 441-9.

11 Gaines H, Sönnerborg A, Czajkowski J, Chiodi F, Fenyö EM, von Sydow M, et al. Antibody response in primary human immunodeficiency virus infection. Lancet 1987; ;:1249-54.

12 Lindgren S, Anzén B, Bohlin A-B, Lidman K. HIV and child-bearing: clinical outcome and aspects of mother-to-infant transmission. AIDS 1991;5: 1111-6.

13 Van de Perre P, Simonon A, Msellati P, Hitimana DG, Vaira D, Bazubagira A, et al. Postnatal transmission of human immunodeficiency virus type 1 from mother to infant. N Engl f Med 1991:325:593-8.

14 Dunn DT, Newell ML, Ades AE, Peckham CS. Risk of human immunodeficiency virus type 1 transmission through breasffeeding. Lancet 1992. 340:585-8.

15 Mitchell $\Omega$, Brown GM, Loftman P, Williams SB. HIV infection in pregnancy: detection, counselling, and care. Pediatric AIDS and HIV Infection 1990;1:78-82.

16 Selwyn PA, Carter RJ, Schoenbaum EE, Robertson VJ, Klein RS, Rogers MF et al. Knowledge of HIV antibody status and decisions to continue or terminate pregnancy among intravenous drug users. $7 A M A$ 1989;261: 3567-71.

17 Johnstone FD, Brettle RP, MacCullum LR, Mok J, Peutherer F, Burns S. Women's knowledge of their HIV antibody state: its effect on their decision whether to continue the pregnancy. $B M 7$ 1990;300:23-4.

18 Hull HF, Bettinger CJ, Gallaher MM, Keller NM, Wilson J, Mertz GJ. Comparison of HIV-antibody prevalence in patients consenting to and declining HIV-antibody testing in an STD clinic. $¥ A M A$ 1988;260:935-8.

19 Hoff R, Berardi VP, Weiblen BJ, Mahoney-Trout L, Mitchell ML, Grady GF. Seroprevalence of human immunodeficiency virus among childbearing Seroprevalence of human immunode
women. N Engl $f$ Med 1988;318:525-30.

20 Novick LF, Berns D, Stricof R, Stevens R, Pass K, Wethers J. HIV seroprevalence in newborns in New York State. FAMA 1989;261:1745-50

21 Ades AE, Parker S, Berry T, Holland FJ, Davison CF, Cubitt D, et al. Prevalence of maternal HIV-1 infection in Thames regions: results from anonymous unlinked neonatal testing. Lancet 1991;337:1562-5.

22 Tappin DM, Girdwood RWA, Follet EAC, Kennedy R, Brown AJ, Cockburn F. Prevalence of maternal HIV infection in Scotland based on unlinked anonymous testing of newborn babies. Lancet 1991;337:1565-7. 
23 Goldberg DJ, MacKinnon H, Smith R, Patel NB, Scrimgeour JB, Inglis J, et al. Prevalence of HIV among childbearing women and women having termination of pregnancy: multidisciplinary steering group study. $B M$ 1992;304:1082-5.

24 Sherr L. HIV and AIDS in mothers and babies. A guide to counselling. Oxford: Blackwell Scientific, 1991:57-68.

25 Boyd KM. HIV infection: the ethics of anonymised testing and of testing pregnant women. Institute of Medical Ethics: working party report. pred Ethics 1990;16:173-8.

26 Landesman S, Minkoff H, Holman S, McCalla S, Sijin O. Serosurvey of human immunodeficiency virus infection in parturients. $尹 A M A$ 1987;258: 2701-3.

27 Lindsay MK, Peterson HB, Feng TI, Slade BA, Willis S, Klein L. Routine antepartum human immunodeficiency virus infection screening in an innercity population. Obstet Gynecol 1989;74:289-94.

28 Wenstrom KD, Zuidema LJ. Determination of the seroprevalence of human immunodeficiency virus infection in gravidas by non-anonymous versu anonymous testing. Obstet Gynecol 1989;74:558-61.

29 Barbacci M, Repke JT, Chaisson RE. Routine prenatal screening for HIV infection. Lancet 1991;337:709-11.

30 Quinn TC, Glasser D, Cannon RO, Matuszak DL, Dunning RW, Kline R, et al. Human immunodeficiency virus infection among patients attending clinics for sexually transmitted diseases. N Engl f Med 1988;318:197-203.

31 Meadows J, Lenkinson S, Catalan J, Gazzard B. Voluntary HIV testing in the antenatal clinic: differing uptake rates for individual counselling midwives. AIDS Care 1990;2:229-33.

(Accepted 10 September 1993)

\section{Appendix}

SUMMARY OF THE RECOMMENDATIONS FROM THE SWEDISH NATIONAL BOARD OF HEALTH AND WELFARE CONCERNING HIV-SCREENING IN PREGNANCY ${ }^{9}$

1 Education and information about HIV in pregnancy should be given to all staff concerned with pregnant women and with newborns before antenatal HIV screening is started. The staff should be educated in medical, psychological, and hygienic issues to be able to inform the patient and feel confident in the work with HIV infected people.

2 The HIV test should be an integrated part of the antenatal care, and preferably performed at the same time as the other blood tests on registration at the antenatal care unit.
Pregnant women can also have the test performed at abortion clinics.

3 Adequate laboratory resources must be available for safe, rapid, and competent investigation of the blood samples. It is important that the time interval between blood sampling and the test result is kept as short as possible to reduce the period of uncertainty and to enable the woman to consider abortion if the test result is positive. Specific routines concerning test results should be used. A negative test result can be reported directly to the unit where the blood sample was collected. Women who have negative HIV test results or who decline the test should be given counselling according to their needs.

4 The woman must be informed about the tests and the reason for offering the test during pregnancy. The information should preferably be oral as well as written.

5 Local laboratories are supervised by the regional laboratories, at which the confirmatory tests should be performed.

6 When a test result is positive or indeterminate the laboratory should inform the responsible obstetrician directly, and then he or she is responsible for giving the information to the patient and for the following measures that need to be taken. There should be a special team with competence in obstetrics and gynaecology, paediatrics, psychology, social work, and infectious diseases within easy reach This team should take care of the counselling and support of the infected pregnant woman and her partner according to their needs. The obstetrician of the team is also responsible for the information to the staff concerned with the care of the patient and for the necessary hygienic precautions to be observed.

7 The result of the HIV test is written in the woman's pregnancy record. The HIV diagnosis must not be disclosed to anybody without the woman's consent. Children born to HIV-positive women need to be followed from birth, and the paediatrician should be notified by the team.

8 Contact tracing according to the law must be undertaken for the woman. Her partner and, where appropriate, her children should have an HIV test performed.

\title{
Relation between birth weight and blood pressure: longitudinal study of infants and children
}

\author{
Lenore J Launer, Albert Hofman, Diederick E Grobbee
}

\section{Department of}

Epidemiology and

Biostatistics, Erasmus

University Medical School, 3000 DR Rotterdam,

Netherlands

Lenore J Launer, research scientist

Albert Hofman, professor

Diederick E Grobbee,

professor

Correspondence to:

Dr Launer.

\section{Abstract}

Objective-To study the relation between birth weight and systolic blood pressure in infancy and early childhood.

Design-Longitudinal study of infants from birth to 4 years of age.

Setting-A middle class community in the Netherlands.

Participants-476 Dutch infants born in 1980 to healthy women after uncomplicated pregnancies.

Main outcome measures-Systolic blood pressure and body weight measured at birth and at 3 months and 4 years of age; the relation between systolic blood pressure and birth weight as estimated by multiple regression models that include current weight and previous blood pressure and control for gestational age, length at birth, and sex.

Results-Complete data were available on 392 infants. At 4 years of age the relation between blood pressure and birth weight appeared to be $U$ shaped; low and high birthweight infants had raised blood pressure. Current weight and previous blood pressure were also positively associated with blood pressure at that age. Low birthweight infants (birth weight $<3100 \mathrm{~g}$ ) had a greater gain in blood pressure and weight in early infancy. High birthweight infants (birth weight $\geqslant 3700 \mathrm{~g}$ ) had high blood pressure at birth, and weight and blood pressure tended to remain high thereafter.

Conclusions-Even among normal infants there seem to be subgroups defined by birth weight in which blood pressure is regulated differently. Future investigations are needed to examine the physiological basis of these differences. Studies of correlates of adult disease related to birth weight should investigate mechanisms related to increased risk separately in infants of low and high birth weight.

\section{Introduction}

An inverse relation between birth weight and cardiovascular disease in adulthood has been reported in retrospective cohort studies. ${ }^{1}$ The suggestion has been made that blood pressure mediates this relation. Indeed an inverse relation between birth weight and blood pressure has been reported in children, adolescents, and adults. ${ }^{2-4}$ Mechanisms for such a relation have been proposed ${ }^{5}$ but are by no means agreed on. ${ }^{6-8}$ Nevertheless, these findings raise the possibility that prenatal as well as postnatal factors are important in the aetiology of disorders in adulthood related to hypertension.

If prenatal factors and factors in early infancy contribute to disease in later life then examining prospectively their relation to blood pressure in the first years of life may help to elucidate this contribution. We examined the relation of birth weight to blood pressure in early infancy and childhood. We also studied the interrelation among birth weight, current 